\title{
REFORMA E PLURALISMO RELIGIOSO: ANTECEDENTES DE UMA RELAÇÃO
}

Alonso S. Gonçalves ${ }^{1}$

Resumo: Como todo o evento é passível de ambiguidades e interpretações, o que se pretende com esse artigo é fazer uma leitura da Reforma perguntando se há uma contribuição da mesma para o que comumente conhecemos hoje como pluralismo religioso. Inegável que a questão do pluralismo religioso não foi pensada por Lutero ou qualquer outro reformador, por circunstâncias históricas. Ainda assim, é possível encontrar fatores que possibilitam tal hipótese com o intuito de demonstrar uma relação possível a ser explorada a partir das contribuições da Reforma para a temática. Por essa razão, o texto se propõe a procurar os antecedentes dessa possibilidade, com o objetivo de contribuir com o diálogo inter-religioso.

Palavras-chave: Lutero. Reforma. Pluralismo Religioso. Diálogo Inter-religioso.

\section{RELIGIOUS REFORM AND PLURALISM: BACKGROUND TO A RELATIONSHIP}

\begin{abstract}
As the whole event is open to ambiguities and interpretations, what is intended with this article is to make a reading of the Reformation asking if there is a contribution of the same to what we commonly know today as religious pluralism. Undeniable that Luther or any other reformer did not think the issue of religious pluralism, by historical circumstances. Nevertheless, it is possible to find factors that make possible this hypothesis in order to demonstrate a possible relation to be explored from the contributions of the Reformation to the theme. For this reason, the text proposes to look for the antecedents of this possibility, in order to contribute to interreligious dialogue.
\end{abstract}

Keywords: Luther. Reform. Religious Pluralism. Interreligious Dialogue.

\section{REFORMA Y PLURALISMO RELIGIOSO: ANTECEDENTES DE UNA RELACIÓN}

Resumen: Como todo el evento es pasible de ambigüedades e interpretaciones, lo que se pretende con este artículo es hacer una lectura de la Reforma preguntando si hay una contribución de la misma para lo que comúnmente conocemos hoy como pluralismo religioso. Inegable que la cuestión del pluralismo religioso no fue pensada por Lutero o cualquier otro reformador, por circunstancias históricas. Sin embargo, es posible encontrar factores que posibiliten tal hipótesis con el propósito de demostrar una relación posible a ser explorada a partir de las contribuciones de la Reforma a la temática. Por esa razón, el texto se propone a buscar los antecedentes de esa posibilidad, con el objetivo de contribuir con el diálogo interreligioso.

Palabras clave: Lutero. Reforma. Pluralismo Religioso. Diálogo Interreligioso.

\footnotetext{
${ }^{1}$ Doutorando em Ciências da Religião. Realiza estudos, com o apoio da FAPESP (Fundação de Amparo à Pesquisa do Estado de São Paulo. E-mail: alonso3134@hotmail.com
} 


\section{INTRODUÇÃO}

A nossa proposta, é pensar a Reforma e sua contribuição para aquilo que denominamos, hoje, de pluralismo religioso. Estabelecer essa relação constitui em tarefa metodológica, considerando fontes (autores) que possam fornecer meios para se pensar nas possibilidades de tal relação - correndo um risco de um possível anacronismo, principalmente quando se propõe uma reflexão a partir de um evento vultuoso como foi (é) a Reforma Protestante e sua polissêmica consequência.

A Reforma, no seu aspecto histórico, tem enfoques e nuances que não permitem abarcar a diversidade de perspectivas de um modo geral. Portanto, a nossa preocupação não se dá, precisamente, com a "história dos acontecimentos", considerando que os "acontecimentos" são como superfície do oceano da história, sendo significativo, os acontecimentos, por aquilo que podem se mostrar nas correntes mais profundas. Esse tem sido o trabalho da conhecida Escola dos Annales. Interessou-se pela "história das estruturas" e não, primeiramente, pela "história dos acontecimentos" (BURKE, 2011, p. 336). Interessa então a história das mentalidades, das estruturas que, de uma forma inevitável, transcende os personagens e acontecimentos e são, inexoravelmente, inseridas novas leituras e perspectivas. Não sem razão, que a história cultural $^{2}$ vem desenvolvendo uma historiografia que atenta para as mentalidades, para as pequenas histórias, valorizando aspectos culturais que de uma maneira indelével se perpétua sem atentar rigorosamente para datação ou personagens definidos como agentes da história.

A tentação de olhar a Reforma com um certo ufanismo é grande. Principalmente por setores conservadores que enxergam na emblemática marca dos 500 anos, fator comprobatório da predileção de Deus por um ramo do cristianismo mundial. Há quem exalte a Reforma com um certo exagero triunfalista, sacralizando personagens e colocando-os como baluartes de um cristianismo purificado dos males de Roma. Obviamente atribuir isso à personagens como Lutero ou Calvino está fora de escopo, precisamente pelo fato que os personagens, sincrônico com a sua realidade histórica, desconhecem as consequências que seus atos teriam e as possíveis intepretações deles. Não há dúvida de que a Reforma contribuiu para a noção de liberdade (livre-arbítrio), mas sabemos que Lutero e Erasmo discordavam quanto aos fundamentos dessa

\footnotetext{
${ }^{2}$ Quanto a metodologia da "História Cultural", ver: BURKE, Peter. O que é história cultural? 2. ed. Rio de Janeiro: Zahar, 2008.
} 
liberdade. Enquanto este último consentia que o ser humano tem a capacidade de optar em favor de Deus e colaborar no processo da salvação; o primeiro compreendia que o ser humano tem uma vontade cativa, portanto um "servo arbítrio" (ALTMANN, 1994, p. 210). Esse exemplo já demonstra as ambiguidades da Reforma e, ao mesmo tempo, o seu alcance.

Não obstante a essas questões, há um consenso de que a Reforma teve um papel decisivo na redefinição da mentalidade do homem moderno e ocidental (PERRY, 2002, p. 244). Mesmo assim, como nos lembra Ernst Troeltsch (1958, p. 28), "uma grande massa dos fundamentos do mundo moderno a respeito do Estado, a sociedade, a economia, a ciência e a arte se originaram com completa independência do protestantismo". Essas duas citações, reforçam a dinâmica da Reforma e sua inegável dialética. Se por um lado a Reforma, sem pretender, favoreceu alguns fundamentos do Estado moderno, por outro lado "nem Lutero nem Calvino defendiam a liberdade política" (PERRY, 2002, p. 244) para tal projeto de Estado. Segundo Marvin Perry (2002, p. 244), para Lutero um bom cristão era um súdito obediente, ou seja, os súditos deviam obedecer às ordens de seus governantes - "Sob hipótese nenhuma era apropriado, a qualquer um que fosse cristão, erguer-se contra seu governo, fosse ele justo ou injusto". Mesmo com essas contradições, a Reforma deixou suas marcas na política e na ciência, sendo um movimento, estritamente, político-religioso.

Como todo o evento é passível de ambiguidades e interpretações, pretendemos fazer uma leitura da Reforma perguntando se há uma contribuição para o que comumente conhecemos hoje como pluralismo religioso. Sabendo que essa questão (pluralismo religioso), não foi pensada por Lutero ou qualquer outro reformador, por circunstâncias históricas. Ainda assim, acreditamos que há uma relação possível a ser explorada a partir das contribuições da Reforma para a temática. Dessa forma, iremos procurar os antecedentes dessa possibilidade.

A fim de demonstrar essa relação, entendemos que há algumas questões que são importantes elencar:

1) Reforma e Modernidade: os aspectos que envolvem a Reforma e as consequências para a noção de Modernidade;

2) A contribuição da Reforma para a Pluralidade: perseguindo conceitos e propostas que abarquem essa relação; 
3) A contribuição da Reforma para o Pluralismo Religioso: o contexto e os fundamentos político-teológicos da Reforma como contribuição para se fomentar o Diálogo Inter-religioso.

Esperamos contribuir para uma discussão em torno do tema do pluralismo religioso (hoje um princípio), como também as possibilidades para o diálogo interreligioso, fomentando a partir dos principais fatores que a Reforma permitem, traçar pontes.

\section{REFORMA E MODERNIDADE}

Modernidade é um conjunto de alguns termos-chave como razão, ciência, técnica, progresso, emancipação, sujeito, historicismo, metafísica, niilismo e secularização. Esses termos ganham contornos e ênfases em diferentes pensadores (ABBAGNANO, 2012, p. 791). A discussão quanto ao surgimento da Modernidade também é volumosa, havendo quem entende que o seu começo se dá em 1492, com o "descobrimento" da América. Outros ainda reivindicam a Revolução Francesa como ponto fulcral. Na filosofia, o debate em torno do surgimento da Modernidade está atrelado aos nomes de Kant e Hegel, havendo uma disputa entre os intérpretes desses pensadores quanto a marcação da Modernidade e sua relação com a razão. ${ }^{3}$ Aqui iremos priorizar Hegel por algumas razões que explicitaremos adiante. Como intérpretes do seu pensamento, optamos por Jürgen Habermas e Manfredo Araújo de Oliveira. Ciente das disputas quanto ao posto de filósofo da Modernidade (Kant ou Hegel), interessa o lugar da Reforma e sua contribuição, para o que se chamou, posteriormente, de Modernidade, em alguns aspectos do pensamento de Hegel. Sabe-se que "a Reforma Protestante foi um acontecimento essencialmente religioso, mas causou ao mesmo tempo profundas transformações políticas, sociais, econômicas e culturais" (MONDIN, 1981, p. 27). Essas transformações da qual fala o filósofo católico Battista Mondin, não foram causadas, objetivamente, pela Reforma, mas a Reforma contribuiu para aprofundar algumas mudanças que já estavam em curso, principalmente com a Renascença. É bom lembrar que a Reforma só foi possível porque um conjunto de acontecimentos culturais envolvendo política, arte, ciência, economia e religião estavam ocorrendo na Europa

\footnotetext{
${ }^{3}$ Manfredo A. de Oliveira faz uma importante discussão entre os dois filósofos no seu texto Ética e racionalidade moderna (São Paulo: Loyola, 1993).
}

Fronteiras: Revista de História | Dourados, MS |v. 19 |n. 34 |p. 49 - 70 | Jul. / Dez. 2017 
(CAVALCANTE, 2017, p. 36). É dentro desse contexto de "concentração singular de invenções [...] descobertas e mudanças de paradigmas que iriam transformar permanentemente a história da humanidade". É nesse centro gravitacional que a Reforma contribuiu para o que depois irá surgir, como acentua Ronaldo Cavalcante (2017, p. 36), “o período ulteriormente denominado Moderno".

O filósofo alemão Georg W. F. Hegel, advogava a ideia de que a Modernidade teve o seu início a partir da Reforma e não, primeiramente, da Revolução Francesa (DICKEY, 2014, p. 358). Não desconsiderando o debate que Hegel promove em torno da Revolução Francesa, procuramos o lugar da Reforma no pensamento do filósofo alemão para o que se propõe nesse momento. Quando Jürgen Habermas (1989, p. 28) pontua o surgimento da Modernidade para Hegel a partir da Reforma, ele o faz a partir de uma chave de leitura, qual seja, a subjetividade - "Hegel descobre em primeiro lugar como princípio da Idade Moderna a subjetividade”. Esse descobrir tem relação com a Reforma, o que veremos adiante. Antes, é preciso compreender que a filosofia da subjetividade em Hegel está ligada à autonomia do sujeito. Seguindo Manfredo A. de Oliveira (1993, p. 72) “a liberdade será concebida como reflexão, auto-relação do espírito a si mesmo, o que vai abrir o horizonte à autonomia do pensamento e da ação humana, à medida que tudo só se justifica se levado ao tribunal do sujeito". Em outras palavras, é a partir da subjetividade, para Hegel, que se dá toda a Modernidade. Esta passa pela mediação subjetiva. Dessa forma, "todas as dimensões da vida do [ser humano] - a religião, a economia, a política, a moral e a arte - foram radicalmente transfiguradas a partir do princípio da subjetividade" (OLIVEIRA, 1993, p. 73). Essa relação do sujeito consigo mesmo é a principal característica da Modernidade, denominada por Hegel, portanto, como subjetividade (HABERMAS, 1989, p. 28). Habermas, como leitor e estudioso do pensamento hegeliano, afirma que a fisionomia da Modernidade em Hegel passa pela subjetividade, por ela a liberdade e a reflexão "A grandeza do nosso tempo consiste em que se reconhece a liberdade, a propriedade do espírito de estar em si” (HEGEL apud HABERMAS, 1989, p. 29).

Qual a relação da subjetividade, como elemento principal na concepção de Modernidade em Hegel, com a Reforma? "Os acontecimentos históricos chaves para a implantação do princípio da subjetividade são a Reforma, a Ilustração e a Revolução Francesa" (HABERMAS, 1989, p. 29). Há três corolários aqui elencados por Habermas em torno da Modernidade, mas nos ocupamos com apenas um, a Reforma. Procurar 
estabelecer no pensamento hegeliano a relação entre subjetividade e Reforma se faz crucial para o que se pretende, o que seja, pontuar a relação entre Reforma e Pluralismo Religioso, sendo que para isso se procura antecedentes dessa relação. Iluminar lugares onde essa relação se faz plausível a fim de abrir conexões entre os dois polos e as possíveis consequências, é tarefa metodológica. A concepção de Hegel de que a Reforma se constitui em chave histórica para a Modernidade, mesmo os proponentes não tendo tal intenção, uma vez que as circunstâncias e a plataforma de debates se davam a partir do contexto político-religioso, a novidade é o elemento da subjetividade que alimenta a Modernidade e Hegel encontra na Reforma a sua ativação. Como isso se dá? "Com Lutero a fé religiosa se torna reflexiva; a solidão da subjetividade e mundo divino se transforma em algo posto diante de nós" (HABERMAS, 1989, p. 29). Esse processo, tornar a fé em reflexão e deslocar o mundo divino para diante de si, foi possível porque a Reforma, quando interpela o sistema religioso sustentado pela Igreja, vai contra uma fé mediada pela autoridade do Papa, bem como também uma tradição que domina o sujeito de suas condições pensantes (HABERMAS, 1989, p. 29).

Manfredo A. de Oliveira (2013, p. 273) traz a temática da liberdade em Hegel e sua associação com a Reforma. Para o filósofo, "a liberdade se fez o grande programa da Modernidade em consequência da Reforma Protestante”. A explicação de Oliveira (2013, p. 273) para essa constatação, é que "na Reforma, a objetividade da verdade é inseparável da subjetividade e da certeza, de modo que o sujeito se torna verdade na medida em que ele [...], apropria-se de si mesmo enquanto ser livre, e a verdade se manifesta no ser livre”. Em que sentido isso foi possível a partir da Reforma? Interpretando Hegel, Oliveira (2013, p. 273) assegura: "Só a Reforma Protestante pode provocar as grandes transformações dos tempos modernos em função da construção de um mundo objetivo a partir do princípio da liberdade”. A liberdade está estritamente ligada à Reforma quando possibilita a construção de um indivíduo reivindicador da sua autonomia. Essa reivindicação passa pela interpretação da Bíblia ${ }^{4}$ com a ideia do livre exame. Michel Foucault, fazendo um estudo da crítica no século XV e XVI, atribuiu à Reforma e sua apropriação política da Bíblia, o principal passo para uma postura crítica e autônoma:

\footnotetext{
${ }^{4}$ Isso se deu não sem ambiguidades, como demonstrou o uso político do texto bíblico com o propósito de fundamentar discursos ideológicos, doutrinários das denominações cristãs.
} 
Numa época onde o governo dos homens era essencialmente uma arte espiritual, ou uma prática essencialmente religiosa ligada à autoridade de uma Igreja, ao magistério de uma Escritura, não querer ser governado desta forma, era essencialmente buscar na Escritura uma outra relação que não aquela ligada ao funcionamento da lição de Deus, não querer ser governado era uma certa maneira de negar, recusar, limitar (digam como quiserem) o magistério eclesiástico, era a volta à Escritura (FOUCAULT, 1990, p. 4).

Voltar-se para o texto bíblico foi a maneira de reivindicar autonomia e, num certo sentido, protesto por não querer ser governado pela autoridade de uma Igreja. Foucault (1990, p. 9) conclui: “Talvez também o fato de que a Reforma, isto é, o que eu acredito ter sido, nas suas raízes mais profundas, o primeiro movimento crítico como arte de não ser governado". Voltaremos a esse ponto quando da disputa de Lutero e Erasmo em torno da leitura bíblica e suas consequências.

Consciente do intenso debate que se trava em torno do tema da "Modernidade" e seu projeto que, para alguns pensadores, segue inacabado; enquanto para outros é possível falar em pós-modernidade. O que se pretendeu foi focar na limítrofe entre Reforma e Modernidade. É possível perceber, pelos autores selecionados, que a Reforma, de maneira mais indireta que direta, com exceção da disputa que se dá quanto a leitura bíblica entre Lutero e Erasmo, ou seja, houve uma polarização entre os dois quanto aos desdobramentos dessa postura livre diante da Bíblia, fomentou os principais elementos da Modernidade. Nesse sentido, alguns corolários da Reforma não foram previstos, até porque o alvo estava travado na questão religiosa. Os desdobramentos do movimento emancipatório que teve dentre outros Lutero e companhia em suas respectivas localidades e problemas, confluiu para que Hegel, por exemplo, colocasse a Reforma como um evento chave no surgimento da Modernidade. A subjetividade e a liberdade, com as potencialidades semânticas desses termos, foi possível ser assimilada a partir da Reforma. Quando é possível demonstrar, a partir da filosofia de Hegel e seus intérpretes, que a Reforma contribuiu para o pensamento ocidental com valores que na contemporaneidade são considerados pilares da sociedade Ocidental como a liberdade, não seria exagero afirmar que a Reforma marcou a pluralidade do mundo quando colocou no ser humano (indivíduo, o sujeito de si) a categoria de pensante tendo a razão (Hegel) como meio e condição para o ser livre. 


\section{A CONTRIBUIÇÃO DA REFORMA PARA A PLURALIDADE}

Depois dos estudos de Mircea Eliade sobre as religiões e suas arqueologias, sabe-se que a pluralidade religiosa no mundo não é recente, principalmente no Oriente. No Ocidente as disputas religiosas fazem parte da história da Europa. Mesmo fora dela (da Europa), houve as Cruzadas, demonstrando que a Religião (com as devidas considerações históricas quanto ao termo), funcionou como principal elemento "civilizador". Esse projeto "civilizatório" deixou suas marcas danosas como a quase extinção das culturas pré-colombianas, quando da colonização da América. Projeto esse em curso com a anuência do poder eclesiástico. Com disputas internas e acordos políticos, a Igreja norteou o caminho da Europa, dominando o saber e a cultura. A primeira cisão na Igreja ocorre em 1054 (Igreja Ortodoxa), estabelecendo uma ruptura com o Oriente. Mas a que causa maior dificuldade para a unidade da Igreja se dá com a Reforma, gestada antes de Lutero, mas levada adiante com todas as consequências pelo monge agostiniano. Com a Reforma, a pluralidade é perceptível no estabelecimento das fronteiras religiosas e políticas. Processo não pacífico, principalmente na Alemanha de Lutero. A pluralidade que a Reforma proporcionou, contribuiu para disputas ideológicas, políticas e teológicas. Erasmo de Roterdã e Thomas Müntzer, são os principais rivais ao pensamento e posicionamento de Lutero, representantes dessa pluralidade emergente. Ainda assim, as disputas religiosas deu lugar ao que ficou conhecido como a Paz de Augsburgo, conduzindo um processo de pacificação entre os territórios e suas respectivas confessionalidade, com violações de ambos os lados, mas ainda assim, um considerável avanço em termos de tolerância religiosa. São esses e outros fatores que, uma vez explorados, poderia responder a seguinte pergunta: Quais são os principais fatores que a Reforma promoveu, favorecendo assim como consequência, a pluralidade?

\section{Reforma e Pluralidade}

Ao que parece a Reforma promoveu a pluralidade, não apenas religiosa, mas também política e ideológica.

Ainda que sejam essas duas expressões, pluralismo e pluralidade, intercambiais, sendo a primeira de caráter mais ideológico, parte-se do pressuposto de que a Reforma contribuiu para a pluralidade, e, como consequência, como entendemos 
hoje, o pluralismo religioso, mais adiante. Importante fazer essa distinção, porque a pluralidade tem um caráter mais valorativo, ou seja, "trata-se do quanto os sistemas religiosos existentes no mundo ou os de uma região específica são, de fato, distintos" (RIBEIRO, 2014, p. 20). Nesse sentido, a pluralidade se constituiu como uma marca da Reforma porque esta favoreceu o aparecimento de novos mecanismos, sistemas e ideias que possibilitou, com consequências, transformações no modus vivendi. A Reforma dá a oportunidade para uma concepção de que é possível haver um acordo em discordar.

O historiador Marvin Perry (2002, p. 244), quando pontua a relação da Reforma com a Idade Moderna, elenca alguns pontos, naturalmente discutíveis, considerados fundamentais para essa relação, e aqui adicionamos a noção de pluralidade. Indubitavelmente a Reforma abriu essa possibilidade, a pluralidade, quando promoveu a ruptura da Igreja, principal instituição, até aquele momento, da sociedade medieval. Aqui há um impulso para o crescimento do Estado moderno, seguindo Perry (2002, p. 244), uma vez que o movimento da Reforma rejeitou totalmente a pretensão do Papa à autoridade temporal. A pluralidade é possível quando há liberdade para se pensar no diferente, no distinto, no contraditório, quando se pensa que o outro tem condição para ser também quem se é. Assim, outro fator que Perry (2002, p. 245) considera um legado da Reforma, é a noção de igualdade: “A Reforma promoveu a ideia de igualdade, que tem raízes na crença judaico-cristã de que as pessoas são todas criaturas de um único Deus”. Parece que Marvin Perry exagera com a ideia de igualdade promovida pela Reforma, uma vez que os personagens não estavam, em primeira hora, interessados em tratar as coisas igualitariamente, principalmente na questão dos camponeses e a reação de Lutero, por exemplo. Como já assinalado, parece ser, mais uma vez, um efeito colateral da Reforma, algo que Lutero ou Calvino, ao que parece, não esperavam um desfecho dessa natureza, pelo menos diretamente. Como já indicado, parte-se de uma história cultural, ou seja, não olha-se, primeiramente, os acontecimentos como um fato em si, mas as reverberações destes acontecimentos em mentalidades e micros histórias. Assim, a possibilidade de se pensar em igualdade se dá a partir do momento em que a Reforma empodera o crente, individualmente, para ser "o seu próprio sacerdote e o mentor de sua própria vida religiosa" (CAIRNS, 1995, p. 223). Buscando a emancipação de um sistema religioso, a Reforma promove, com aquilo que depois vamos conhecer como sacerdócio universal de todos os crentes, um salto na concepção de mundo tendo como porta de entrada a ideia de que era possível 
conceber a vida para além dos ditames de Roma, símbolo, naquele momento, de opressão.

Outro fator que possibilita pensar em pluralidade a partir da Reforma, é a noção de ética e individualidade. A Renascença tem fundamental parcela nisso. A sua vertente italiana, mais precisamente, e que depois foi possível em outros lugares da Europa, como na Alemanha de Lutero, hasteou bandeiras de oposição aos dogmatismos. A busca do movimento foi pelos marcos antigos, portanto o que é antigo, passa a ser valorizado e buscado (NOGARE, 1988, p. 57-59). A Renascença não propõe rupturas abruptas como foi a Reforma, mesmo sendo um ingrediente importante para o seu desfecho. Seguindo Perry (2002, p. 245), o aparecimento de uma ética individualista se dá com a pretensa possibilidade de interpretar a Bíblia, uma vez que a Reforma propaga de que não poderia haver um intérprete oficial das Escrituras. Com isso, "ficava a cargo do indivíduo a terrível responsabilidade de interpretar a Bíblia de acordo com os ditames de sua consciência". Embora a intenção fosse essa, do livre exame das Escrituras, isso não se constituiu em princípio, porque o texto bíblico continuou sendo manipulado politicamente por quem detinha a nova tradição. De qualquer forma, a discussão quanto a possibilidade do livre exame contribuiu para uma ética individualista, o que terá consequências, principalmente, com uma ética voltada para o capitalismo e sua relação com o protestantismo, como demonstrou Max Weber (2001).

\section{Erasmo e Lutero}

Erasmo de Roterdã e Lutero tornam-se emblemáticos para se pensar em uma pluralidade emergente. A discussão entre os dois em torno do texto bíblico e a possibilidade de interpretação com os respectivos mecanismos para isso, sinaliza o que iria, no protestantismo contemporâneo, ser a principal característica deste, a sua natureza plural. A pluralidade está aí, quando o debate é travado a partir da noção de liberdade, interpretação da Bíblia e verdade.

Erasmo não poupou críticas ao sistema religioso vigente. No clero ele concentrava as suas principais, ferozes e jocosas críticas, tornando-se persona non grata para os católicos, mas não distantes desses por conta da tradição. Suas obras foram elencadas no Índex, recomendando cautela com suas falas e textos (REALE; ANTISERI, 2005, p. 69). A relação de Erasmo com Lutero, no início, se dá quando o reformador viu neste alguém para endossar suas críticas à Roma. O desentendimento 
entre os dois acontece em torno do livre arbítrio. Pressionado para se definir entre o reformador e a Igreja, Erasmo escreve De Libero Arbítrio, contrariando Lutero. Este texto se coloca frontalmente contra alguns pressupostos da Reforma defendidos por Lutero. No texto em questão, Erasmo defende a vontade livre, confrontando Lutero que tem como ponto de partida o determinismo. A reação do reformador se deu com $D e$ Servo Arbítrio. Para Lutero "a mera hipótese de uma ação livre do homem, independente de Deus ou em cooperação com ele, já constituía uma limitação da liberdade de Deus" (ROUANET, 1987, p. 284-285). Eis um ponto de abertura à pluralidade. A discordância entre os dois quanto a liberdade - sendo esse um pilar da Modernidade, como vimos e, em Hegel, a Reforma impulsionou, o que demonstra a ambiguidade dos postulados da Reforma -, se dá na capacidade ou não da razão determinar as escolhas. Como renascentista, Erasmo não abria mão do pressuposto da liberdade, base para todos os preceitos morais (ROUANET, 1987, p. 285). A antropologia pessimista de Lutero, antropologia essa que alimentará a teologia reformada, deixava Erasmo inquieto. Para ele o ser humano "é por natureza dotado de razão, e ela o impele à concórdia e à solidariedade" (ROUANET, 1987, p. 285). A disputa entre Erasmo e Lutero em torno do livre arbítrio, reforça um pouco mais a ideia de que algumas consequências da Reforma para a Modernidade são efeitos colaterais, algo que escapou do controle, mesmo com resistência. É algo que foi além do que se planejou, se é que houve tal planejamento. O mesmo Lutero que reclama e questiona diante de um sistema religioso corrompido, clamando por emancipação política e religiosa, é o mesmo, quando contrariado em suas posições, que vocifera contra Erasmo quando este quer colocar no humano a condição primeira das escolhas. E não se trata de Bíblia e sua aceitação. Erasmo foi um dos pioneiros na tradução do Novo Testamento e quando criticava o clero, fazia a partir dos Evangelhos. Seguindo Sergio Paulo Rouanet (1987, p. 286), "não é mais a Bíblia, com sua doutrina da queda e do pecado original, que é invocada para dirimir a questão, e sim a filosofia natural, independente de qualquer autoridade e qualquer ortodoxia". No caso de Lutero, estava se questionando uma autoridade (a Igreja), mas no lugar dela se estabelecia uma ortodoxia (a Bíblia). Nesse sentido a pluralidade foi disputada, agora em torno da interpretação da Bíblia e as condições para isso.

Para conceber a pluralidade - ideia de que é possível haver diferentes concepções e modos de entender algo, gerando, com isso, posturas e comportamentos -, 
a noção de verdade se constitui tema principal. Quando se abre a possibilidade de compreender a verdade com diferentes vertentes e não apenas uma - como é o caso do fundamentalismo presente no protestantismo hodierno que se alimenta de uma retórica política alegando pressupostos bíblicos com o propósito de alimentar um discurso enrijecido e cerceador - torna possível a visão plural do mundo. O caso de Erasmo e Lutero é imprescindível, porque ambos protagonizam duas posturas do que seria adiante os protestantismos, ou seja, a sua dimensão plural. O debate em torno da verdade, ou o critério para ela, abre um debate importante para a compreensão do outro e suas questões, mas principalmente sua concepção religiosa. Nesse sentido, a Reforma antecipa a noção de direitos, quando dá condição para que o outro tenha dignidade nas suas escolhas.

Num primeiro momento Lutero questiona o domicílio da verdade na Igreja. Isso ele faz quando escreve o Manifesto à nobreza alemã e A igreja no cativeiro da Babilônia. Nesses textos, Lutero passa de um crítico da Igreja para um questionador da regra de fé da Igreja, ou seja, ele estabelece um novo critério religioso que, agora, não passa mais pela Igreja e seus concílios que, segundo Lutero, continham erros, porque eram feitos por homens. É nesse momento que o monge agostiniano passa de questionador para um líder reformador. Não por acaso que Johann Eck fica escandalizado com Lutero quando este nega a autoridade do Papa e da Igreja em assuntos religiosos. Dar-se um rompimento em torno do que se concebia como verdade quando Lutero muda o eixo, da Igreja para o crente: "Todos os cristãos têm a capacidade de discernir e de julgar o que é certo ou errado em questões de fé" (POPKIN, 2000, p. 26). Agora são as Escrituras o critério de verdade, superando o Papa em sua autoridade. Para Lutero a liberdade está condicionada à consciência, sendo a consciência condicionada às Escrituras. Eis o novo critério de verdade (POPKIN, 2000, p. 27). Questionando os critérios outrora da verdade, está aberto as disputas quanto aos novos critérios para o conhecimento religioso, ou seja, há um caminho aberto para a pluralidade de concepções e entendimentos. Não é possível afirmar, peremptoriamente, que Lutero não dimensionava que sua postura teria consequências irreversíveis na posteridade. Como bem pontua Richard Popkin (2000, p. 29), “a caixa de Pandora aberta por Lutero em Leipzig viria a ter consequências extremamente amplas não só na teologia, mas em todos os domínios intelectuais do ser humano". Uma vez aberta a possibilidade de lidar com o novo, ou seja, haver outros critérios para a verdade, busca- 
se o verdadeiro critério. Se por um lado a Igreja acusava a consciência de não ser confiável, portanto haveria de ter um elemento discernidor, nesse caso a Igreja, para dar orientação; por outro lado Lutero insistia que o elemento discernidor não seria (não poderia) ser a Igreja, mas o crente. Não sem razão, que "um dos argumentos apresentados pelos católicos ao longo de toda a Reforma foi que o critério de Lutero levaria à anarquia religiosa" (POPKIN, 2000, p. 29). A mudança de critério para a verdade levou à pluralidade, principalmente quando "qualquer um poderia recorrer à sua própria consciência e manter que o que lhe parecia a verdade era verdade" (POPKIN, 2000, p. 29). Lutero chegou a ver o surgimento da pluralidade quando, por exemplo, os anabatistas acirram ainda mais os postulados da Reforma. A mudança de critério, ocasionou uma diversidade religiosa na Europa, levando reformadores a condenar como heréticos aqueles que, no uso de suas consciências, promoveram movimentos a partir de outros critérios de verdade. Um desses critérios, foi o acesso à terra, como foi o caso dos camponeses liderados por Thomas Müntzer, por exemplo.

Para Lutero o critério de verdade se dá na Bíblia. Como fonte da verdade e critério último, até porque era preciso apresentar um, a Bíblia é o único recurso de Lutero diante da Igreja. A premissa era: "Tudo o que nós sabemos de Deus e da relação homem-Deus nos é dito pelo próprio Deus na Escritura. Esta, portanto, deve ser entendida com rigor absoluto, sem interferência de raciocínios e glosas metafísicoteológicas” (REALE; ANTISERI, 2005, p. 73). Colocar na Bíblia o critério de verdade, abre a possibilidade de interpretações. Essas intepretações, dentro da própria Bíblia, se constitui plural. A liberdade diante da Bíblia, abre possibilidades inimagináveis. Quando Lutero se viu diante dessa pluralidade de perspectivas e interpretações com o, agora, único critério de verdade, "pouco a pouco foi se tornando dogmático e intransigente, pretendendo, em certo sentido, estar dotado daquela 'infalibilidade' que contestara o Papa” (REALE; ANTISERI, 2005, p. 74). Lutero viu a pluralidade e não gostou do que viu. Erasmo tinha alertado Lutero quanto a obscuridade de trechos das Escrituras, e que por isso, era preciso contar com a sabedoria da Igreja (tradição) para orientar. Já Lutero, insistia de que "para encontrar as verdades basta consultar as Escrituras" (POPKIN, 2000, p. 32). O livre exame, do qual Foucault atribuiu o surgimento do pensamento crítico, não funcionou do jeito que Lutero poderia ter imaginado, principalmente quando o meio para se conhecer a verdade contida nas Escrituras foi colocado sob responsabilidade do Espírito Santo. Ingenuidade ou não, 
para Lutero o Espírito Santo não permitiria a dúvida e a incerteza. A terceira pessoa da Trindade não colocaria "em nossos corações opiniões incertas, mas sim afirmações da maior firmeza" (LUTERO apud POPKIN, 2000, p. 33). Ao que parece, Lutero não confiou tanto assim na figura do Espírito Santo quando viu que um dos principais postulados da Reforma, a liberdade da fé, se tornou em algo que ele não pode controlar. Seria por essa razão que Lutero induziu os Príncipes que controlassem a vida religiosa do povo, "chegando até a exortá-los a ameaçar e punir todos aqueles que desleixavam as práticas religiosas"? (REALE; ANTISERI, 2005, p. 74). Para quem proclamou uma emancipação diante de um sistema opressor que instrumentalizava as indulgências como discurso político castrador da autonomia do humano, Lutero não foi diferente quando passou aos Príncipes a tutela espiritual do povo como patrimônio político destes, surgindo, então, a união entre Igreja e Estado na Alemanha (REALE; ANTISERI, 2005, p. 74). Como um pêndulo, Lutero poderia não ter se dado conta (ou se deu e foi tarde demais para revogar?) que os principais pressupostos da Reforma abriria outros pressupostos e desses não se teria mais o controle, mesmo que tentasse.

A Reforma, nesse sentido estrito, não só contribuiu como também protagonizou a pluralidade. Estabelecer a consciência como critério de verdade, abriu margem para a subjetividade e a liberdade, como Hegel entende que a Reforma promoveu. Ao mesmo tempo em que se estabelece essas categorias para ser quem se é, concomitantemente, abre-se a possibilidade da objeção, do contraditório, do diferente, do plural.

\section{A CONTRIBUIÇÃO DA REFORMA PARA O PLURALISMO RELIGIOSO}

A Reforma, como consequência do que a antecedeu, como toda a discussão que o humanismo proporcionou, contribuiu para o aprofundamento da pluralidade. A partir disso, ao que parece, a pluralidade está estabelecida em alguns eixos que a Reforma, como hipótese, não dimensionou a proporção que teria, por isso os efeitos colaterais. As ideias embrionárias que a Renascença fomentou e que a Reforma levou até as últimas consequências, como igualdade, liberdade, individualidade, consciência e interpretação da verdade, são como eixos para se pensar a pluralidade.

Agora, procuramos outra relação a partir daquilo que já foi explicitado. A pergunta que queremos responder é: Uma vez a Reforma favorecendo a pluralidade, 
qual a relação que é possível fazer entre Reforma, pluralismo religioso e diálogo interreligioso?

Este tópico será dividido em duas etapas:

1) A relação entre Reforma e Pluralismo Religioso considerando o que foi colocado acima quanto à pluralidade, procurando uma relação possível entre a Reforma e o pluralismo religioso;

2) Reforma e Diálogo Inter-religioso - as principais consequências da Reforma e as possíveis aberturas como contribuição ao diálogo inter-religioso, focando no "espírito protestante" como elemento crítico diante do contexto atual.

Como o interesse é buscar algo que possa anteceder a relação entre Reforma Protestante e Pluralismo Religioso, tratar este tópico com esses subitens, possibilita contribuir para um tema atual e imprescindível no momento, como é o pluralismo religioso. Importante fazer essa relação, principalmente quando há escassez de reflexão em torno desse tema envolvendo o protestantismo, ${ }^{5}$ mais especificamente no contexto latino-americano.

\section{Reforma e Pluralismo Religioso}

A Reforma tem parcela preponderante no surgimento (ou afirmação) da Modernidade. Para Hegel, "a Reforma é o sol que a tudo ilumina, que se seguiu ao avermelhado da madrugada que observamos no término da Idade Média. [...] Esta é a essência da Reforma: o Homem, na sua própria natureza, está destinado a ser livre" (HEGEL apud ALVES, 2005, p. 51). O tema da liberdade, na Reforma, significou a possibilidade de "um discurso com uma nova temática que colidia com os arranjos ideológico-teológicos dominantes" (ALVES, 2005, p. 49). Mesmo com os efeitos inesperados, principalmente para Lutero, a Reforma propugna uma nova leitura de mundo. Para usar o exemplo de Richard Popkin, Lutero abriu uma caixa de Pandora e o resultado, mesmo com o alerta de Erasmo, foi inesperado, ou seja, impossível de ser remediado. Os critérios para acessar a verdade muda e com a mudança o conflito de interpretações está dado. Não apenas esses, mas também os conflitos religiosos,

\footnotetext{
${ }^{5} \mathrm{Na}$ Europa esse tema, Pluralismo Religioso e Teologia Protestante, é frequente por conta da tarefa missionária que conduziu os protestantes missionários para o Diálogo Inter-religioso, principalmente quando minoria em lugares onde o cristianismo não era maioria. Na América Latina, ainda é pequena a reflexão e produção de textos que procuram pensar a teologia protestante e sua contribuição para o Pluralismo Religioso e, como consequência, o Diálogo Inter-religioso.
}

Fronteiras: Revista de História | Dourados, MS |v. 19 | n. 34 | p. 49 - 70 | Jul. / Dez. 2017 
demonstrando que a Reforma, definitivamente, fornece a chave para o pluralismo religioso. Quem, mais uma vez, assegura isso, é Jürgen Habermas: "Os conflitos religiosos causados pela Reforma, e com os que não puderam ser acabados pelos editos de tolerância autoritários promulgados desde cima, também se resolveram finalmente com o reconhecimento da liberdade religiosa" (apud CAVALCANTE, 2017, p. 49). A história da Igreja colhe o aparecimento de inúmeros grupos e movimentos com questões das mais diversas possíveis no campo religioso. Isso só é possível, abertamente, porque a Reforma concretiza-se como um farol que se pode mirar para reivindicar emancipação político-teológica, inclusive dos reformadores. Ao que parece, o pluralismo religioso encontra-se germinado na Reforma. Quando se tem a possibilidade de questionar um padrão oficial de crenças e condutas e, dessa possibilidade, conceber uma sociedade onde há sujeitos livres que, não mais, são controlados pelo dogma, mas antes são inseridos em um espírito crítico; quando o texto bíblico é colocado nas mãos de gente que agora pode fazer um exame de critérios quanto a interpretação da verdade; esses elementos configuram o pluralismo religioso de maneira sine qua non. Não por acaso, que o pesquisador Wagner Lopes Sanchez (2005, p. 37) concebe o pluralismo religioso como um "modo de compreensão da religião que ultrapassa os limites da tradição". Nesse sentido, a tradição é questionada e outra surge no lugar. Não há dúvida de que a Reforma produziu tradição - tanto que a teologia protestante irá surgir a partir dela -, mas a Reforma promoveu a ruptura de uma tradição e o surgimento de outra. Quando essa ruptura e recriação de tradição acontece, o pluralismo religioso ganha contornos e possibilidades, até então, inimagináveis. Sanchez (2005, p. 39) faz uma importante distinção, mas conectadas, entre pluralidade e pluralismo: "Enquanto a pluralidade tem a ver com a possibilidade de ação de sujeitos religiosos (individuais e coletivos), o pluralismo religioso supõe condições objetivas, inclusive legais, que favoreçam a existência e afirmação desses sujeitos”. Desdobrando essa assertiva, entendemos que, num primeiro momento, a Reforma favoreceu a pluralidade pelas razões já elencadas e, num segundo momento, favoreceu o pluralismo religioso quando as bases políticoideológica da Reforma se assentam. "Enquanto o conceito de pluralidade religiosa se refere à existência de diversas visões religiosas e à liberdade de ação para [...] grupos religiosos, o conceito de pluralismo religioso supõe o [seu] reconhecimento" (SANCHEZ, 2005, p. 39). Esse reconhecimento jurídico, político e teológico aparece no contexto da Reforma. Onde se encontra esse reconhecimento para o estabelecimento de 
um pluralismo religioso de direito? No que ficou conhecido como a Paz de Augsburgo. Um tratado assinado entre Carlos V, imperador, conhecido como o "salvador do catolicismo na Alemanha" e os "Estados evangélicos". O tratado deu a possibilidade quanto à escolha da própria religião em cada território, ficando os seus súditos obrigados a aceitar a escolha do seu Príncipe. O resultado da Paz de Augsburgo foi o estabelecimento da tolerância oficial aos protestantes no império (MOELLER, 2014, p. 310-319). Esse tratado, se constituiu importante porque é dado o início da "era dos diálogos religiosos" (MOELLER, 2014, p. 316). Diálogo imprescindível para se terminar com anos de disputas religiosas. Sabe-se que o tratado celebrou a paz entre católicos e protestantes (luteranos), deixando claramente que quem não pertencesse a nenhuma das duas religiões, não deveriam ser incluídos na presente paz, "mas antes ser totalmente excluídos dela" (BETTENSON, 2011, p. 324). De qualquer forma, o elemento oficial é constituído, permitindo, assim, a pluralidade religiosa. Além disso, a Paz de Augsburgo admite a possibilidade de mudar de religião (território), caso não concordasse com a opção religiosa do Príncipe (ALTMANN, 1994, p. 132).

O intento aqui, é procurar antecedentes para uma relação entre Reforma Protestante e Pluralismo Religioso. Poderia ser um anacronismo essa tentativa, uma vez que a pluralidade religiosa, não era uma preocupação no período da Reforma. Como já sinalizamos, a tentativa aqui é iluminar o terreno a fim de encontrar indícios (fatores) que levem a configurar essa relação. Walter Altmann (1994, p. 137), estudioso do pensamento de Lutero, quando comenta o episódio da Paz de Augsburgo, abre essa possibilidade da qual nos aventamos, ressaltando, portanto, que não é possível retroprojetar a nossa realidade de pluralidade religiosa para os tempos de Lutero. Esse, como outros temas, que aqui estamos chamando de efeitos colaterais da Reforma, não estava na pauta da Reforma e, muito menos, na mentalidade da época de Lutero a coexistência de uma sociedade religiosamente pluralista, indubitavelmente. Por outro lado, como efeito colateral da Reforma, os "conceitos teológicos da liberdade de consciência de fé, [...] do sacerdócio universal dos crentes e da Igreja enquanto comunidade e povo de Deus, entre outros, têm em si uma tendência a evoluírem na direção da tolerância e do pluralismo religioso" (ALTMANN, 1994, p. 137). O pluralismo religioso não surge diretamente na Reforma, mas embrionariamente ele está

\footnotetext{
${ }^{6}$ Isso indica que o "problema" com outras religiões já estava presente. Possivelmente uma referência aos turcos otomanos (mulçumanos), que ameaçavam invadir o império alemão via Viena (Áustria).
}

Fronteiras: Revista de História | Dourados, MS |v. 19 | n. 34 | p. 49 - 70 | Jul. / Dez. 2017 
lá. A Reforma não apenas possibilitou a pluralidade, pelas razões já colocadas, como também lançou as bases para se pensar no pluralismo religioso contemporâneo. Julgamos que as fontes primárias para se pensar no pluralismo religioso, ainda que não estejam evidentes por razões históricas, encontram-se na Reforma. Nesse sentido, o universo protestante agrega algumas categorias que permitem pensar o pluralismo religioso e, como consequência, dialogar com as religiões a partir de algumas chaves de leitura, na tentativa de dizer que o protestantismo tem, na sua gênese, elementos palpáveis para contribuir e criticar. Trata-se de procurar alocar algumas características políticas e teológicas da Reforma dentro da temática do pluralismo religioso, uma vez reconhecido como princípio.

\section{Reforma e Diálogo Inter-religioso}

Há resistência para se conceber o pluralismo religioso e o diálogo interreligioso em fileiras protestantes na contexto latino-americano. Setores conservadores têm resistência quanto a possibilidade de sentar à mesa para um diálogo aberto e honesto sobre questões prementes. A noção de religião, com suas principais características como ritos, mitos, doutrinas, liturgias e ética, valem muito mais para os outros com suas religiões do que, propriamente, para o cristianismo de segmento protestante. As vezes tem-se a impressão que o cristianismo não é uma religião, mas sim uma construção sobre-humana e sem vínculo algum com uma cultura, língua e geografia. Quando se admite o pluralismo religioso como um fato, não o admite como um princípio. Alister McGrath (2007, p. 173) quando fala do pluralismo religioso, por exemplo, faz essa distinção claramente: "O fenômeno básico do pluralismo não é nada novo. Nova é a resposta intelectual a esse fenômeno: a sugestão de que a pluralidade de crenças não é meramente uma questão de fato observável, mas é teoricamente justificada". Para o autor, admitir a existência do pluralismo religioso não é difícil, porque ele está aí, patente aos olhos, ou seja, os dados empíricos confirmam isso. O complicador é admitir, para a fé protestante que ele professa, que há uma justificativa plausível (lê-se, teologicamente) para a coexistência das diversas religiões. O que está em questão para McGrath (2007, p. 173), é que o pluralismo religioso coloca em xeque a noção de verdade. A verdade está com um grupo (alguém), e reivindicar isso em um contexto de pluralismo soa "fascismo", por essa razão "a primeira vítima da agenda pluralista prescritiva é a verdade". A verdade é o conjunto doutrinário estabelecido por confissões que representam, definitivamente, o cerne da fé protestante, constituindo 
assim o que seja ortodoxia. De qualquer forma, a postura de McGrath (2007, p. 200) não está destoada do universo protestante. A Reforma possibilitou isso. O que o autor não atenta para a sua análise do pluralismo religioso, é que ao atribuir o pluralismo religioso à agenda modernista e ao projeto do Iluminismo, se equivoca quando não trata da influência da Reforma para a própria concepção de Modernidade. Procurar estabelecer uma dicotomia entre Reforma e Modernidade, não é possível fazer. Antes, ao contrário, "a Reforma já nasceu plural, [...] como um dos primeiros grandes marcadores históricos da Modernidade" (BURITY, 2016, p. 72). Para o desconforto de alguns, como do próprio McGrath, a Reforma não ficou circunscrita ao debate teológico. Como bem lembra Joanildo Burity (2016, p. 72), a Reforma vai além disso, e desencadeia "sonhos de liberdade e igualdade neste mundo". Não é possível haver liberdade e igualdade de maneira uniformizada, somente plural. Definitivamente reivindicar um discurso hegemônico, uma postura política unívoca e uma interpretação autoritária para o protestantismo, não é possível. A tentação em querer estabelecer uma verdade inquestionável da qual todos devessem seguir, não condiz com o "espírito protestante". Rubem Alves (2005, p. 112-113) alerta de que todas as vezes que se procurou fazer isso, ou seja, estabelecer um absoluto, produziu-se ídolos. O "espírito protestante" que se alimenta da subjetividade, da liberdade, da consciência e dos critérios de verdade, não expressa o que se tornou a fé protestante em fileiras conservadoras. Antes, esse "espírito protestante" não procura estabelecer certezas, mas alimenta-se da busca - "a fé proíbe o dogma" (ALVES, 2005, p. 110). É nesse sentido, que Paul Tillich popularizou a expressão "princípio protestante". A Reforma possibilita o seu surgimento, mas não tem condições de sujeitá-lo. O "princípio protestante" surge “a partir do fenômeno histórico da Reforma Protestante, mas não como atributo essencial de suas expressões institucionais ou confessionais" (BURITY, 2016, p. 74).

Com essas características explícitas e implícitas, é possível dizer que a Reforma não apenas possibilitou maior abertura para o diálogo inter-religioso, como também convoca para que seus herdeiros o promova. Como um grande guarda-chuva, a Reforma abriu a possibilidade de se ter vozes dissonantes e interpretações polissêmicas. Falam conservadores com seus discursos carregados de ortodoxia, com posturas político-ideológica questionáveis diante da realidade de um mundo que necessita de 
diálogo e tolerância; ${ }^{7}$ mas também falam protestantes progressistas que procuram se engajar em movimentos que promovem a paz, a justiça social e a luta por direitos humanos.

\section{NA ESTEIRA DA REFORMA: PARA NÃO CONCLUIR...}

Nesses 500 anos da Reforma (2017), é possível fazer um duplo exercício. Um primeiro olhar para o passado e a tentativa em fazer possíveis leituras desse evento, tendo consciência de que podem estar equivocadas, por razões hermenêuticas e diacrônicas. Um segundo olhar é para o futuro. Pensar o futuro envolve uma pergunta, por parte daqueles que tem na Reforma Protestante a sua tradição de fé e, com essa fé, procura contribuir para um mundo possível: como herdeiros da Reforma, o que é possível pensar e fazer diante dos desafios da contemporaneidade? Desafios que envolvem ecologia, política, gênero, capitalismo, trabalho, questões indígenas, religiões e muitos outros. A Reforma, no meu entender, representa a possibilidade na construção de que é possível, podendo ser de maneira proativa, mas também crítica, dentro do “espírito protestante".

Com a temática do pluralismo religioso, a Reforma, por ser plural, fornece elementos suficientes para fomentar o diálogo como também, a partir do "princípio protestante", denunciar estruturas, religiões, movimentos que não dignificam o ser humano. Se os pretensos herdeiros da Reforma abrir mão do legado plural, contestatório e dinamizador do "espírito protestante", invariavelmente deixará de contribuir para a construção de um tempo melhor nos próximos anos.

\section{REFERÊNCIAS BIBLIOGRÁFICAS}

ABBAGMAnO, Nicola. Dicionário de filosofia. 6. ed. São Paulo: Martins Fontes, 2012.

ALTMANN, Walter. Lutero e libertação. São Paulo: Ática, 1994.

\footnotetext{
${ }^{7}$ A mídia constantemente exibe confrontos e intolerância envolvendo protestantes. O que se presenciou em Charlottesville (EUA), confronto direto entre negros e brancos, tem a legitimidade de grupos que professam o protestantismo e a supremacia branca. No Rio de Janeiro (Brasil), há igrejas que incentivam e promovem passeatas pelas ruas com cartazes e palavras de ordem contra mulçumanos. Além desses dois casos, que poderiam ser reproduzidos, ocorrem, com certa frequência, ataques verbal e, infelizmente em alguns casos, físicos contra religiões de matriz africana. Esse último grupo religioso, são vítimas do crime organizado que nutrem uma certa percepção religiosa de caráter pentecostal comunidades do Rio.
}

Fronteiras: Revista de História | Dourados, MS |v. 19 | n. 34 |p. 49 - 70 | Jul. / Dez. 2017 
ALVES, Rubem. Religião e repressão. São Paulo: Teológica/Loyola, 2005.

BETTENSON, H. Documentos da Igreja cristã. 5. ed. São Paulo: ASTE, 2011.

BURITY, Joanildo. "Ainda uma chance para o 'princípio protestante'? Sobre fé, ideologia e muitas histórias pelo meio... e nas margens". In: REBLIN, Iuri Andréas; SINNER, Rudolf von (Orgs.). Reforma: tradição e transformação. São Leopoldo: Sinodal, 2016, p. 69-91.

BURKE, Peter. "A história dos acontecimentos e o renascimento da narrativa". In: BURKE, Peter (Org.). A escrita da história: novas perspectivas. São Paulo: UNESP, 2011, p. 335-356.

CAIRNS, Earle E. O cristianismo através dos séculos: uma história da Igreja cristã. 2. ed. São Paulo: Vida Nova, 1995.

CAVALCANTE, Ronaldo. As relações entre protestantismo e modernidade: história e memória. São Paulo: Paulinas, 2017.

DICKEY, Laurence. "Hegel, a religião e a filosofia". In: BEISER, Frederick C. (Org.). Hegel. São Paulo: Ideias \& Letras, 2014, p. 353-405.

FOUCAULT, Michel. "O que é a crítica? [Crítica e Aufklärung], 1990. Disponível em: $<$ http://portalgens.com.br/portal/images/stories/pdf/critica.pdf>. Acesso em: 23 ago. 2017.

HABERMAS, Jürgen. El discurso filosófico de la modernidad. Madrid: Taurus, 1989.

McGRATH, Alister. Paixão pela verdade: a coerência intelectual do evangelicalismo. São Paulo: Shedd Publicações, 2007.

MOELLER, Bernd. "A era de ampliação e consolidação da Reforma (1525-1555)". In: KAUFMANN, Thomas [et. al.] (Orgs.). História ecumênica da Igreja: da alta Idade Média até o início da Idade Moderna. São Paulo/São Leopoldo: Loyola/Paulus/Sinodal, 2014, v. 2, p. 302-324.

MONDIN, Battista. Curso de filosofia: os filósofos do Ocidente. 8. ed. São Paulo: Paulus, 1981, v. 2.

NOGARE, Pedro Dalle. Humanismos e anti-humanismos: introdução à antropologia filosófica. 11. ed. Petrópolis: Vozes, 1988.

OLIVEIRA, Manfredo de A. A religião na sociedade urbana e pluralista. São Paulo: Paulus, 2013.

OLIVEIRA, Manfredo de A. Ética e racionalidade moderna. São Paulo: Loyola, 1993.

PERRY, Marvin. Civilização ocidental: uma história concisa. São Paulo: Martins Fontes, 2002.

POPKIN, Richard. História do ceticismo: de Erasmo a Spinoza. Rio de Janeiro: Francisco Alves, 2000.

REALE, Giovanni; ANTISERI, Dario. História da filosofia: do humanismo a Descartes. 2. ed. São Paulo: Paulus, 2005, v. 3.

RIBEIRO, Claudio de Oliveira. Pluralismo e libertação. São Paulo: Paulinas, 2014.

ROUANET, Sergio Paulo. As razões do Iluminismo. São Paulo: Companhia das Letras, 1987. 
SANCHEZ, Wagner Lopes. Pluralismo religioso: as religiões no mundo atual. São Paulo: Paulinas, 2005.

TROELTSCH, E. El protestantismo y el mundo moderno. 2. ed. México: FCE, 1958.

WEBER, Max. A ética protestante e o espírito do capitalismo. São Paulo: Centauro, 2001.

Recebido em: 05/08/2017

Aprovado em: 30/10/2017 